\title{
Effect of genistein on cholesterol metabolism-related genes in a colon cancer cell line
}

\author{
Maria Notarnicola Caterina Messa $\cdot$ Antonella Orlando • \\ Benedetta D'Attoma - Valeria Tutino - Rosemary Rivizzigno • \\ Maria Gabriella Caruso
}

Published online: 4 March 2008

(C) Springer-Verlag 2008

\begin{abstract}
The major soy-derived isoflavones such as genistein has been demonstrated to possess anticarcinogenic activity in animal model systems. The present study was designed to investigate the effects of isoflavone genistein exposure at concentrations ranging from 0.01 to $50 \mu \mathrm{M}$ on the LDL receptor and HMG-CoA reductase gene expression in the estrogen receptor positive DLD-1 human colon cancer cell line. LDL receptor and HMG-CoA reductase gene expressions were evaluated by reverse transcription followed by real-time PCR. Genistein induced an increase of LDL receptor gene expression and later decrease of HMG-CoA reductase mRNA expression in DLD- 1 cells. These findings provide direct evidence on the role of genistein in regulating LDL receptor and HMG$\mathrm{CoA}$ reductase gene expression in colon cancer.
\end{abstract}

Keywords Genistein LDL receptor .

HMG-CoA reductase $\cdot$ Colon cancer

\section{Introduction}

Soybeans contain about $40 \%$ protein, and depending on the processing procedure, the protein content can reach over $90 \%$ as in soy protein isolate (SPI) that is usually used in soy-based infant formulas [39]. Most of the attention in soy studies has been focused on the proteins and their associated isoflavones (ISF). Epidemiological evidences suggest

M. Notarnicola - C. Messa - A. Orlando · B. D'Attoma .

V. Tutino $\cdot$ R. Rivizzigno $\cdot$ M. G. Caruso $(\square)$

Laboratory of Biochemistry,

National Institute for Digestive Diseases,

Via della Resistenza, 70013 Castellana Grotte (Bari), Italy

e-mail: gabriella.caruso@libero.it that soy consumption is linked to a lower incidence of chronic diseases including coronary heart disease, atherosclerosis, Type 2 diabetes, osteoporosis, and certain types of cancer such as prostate and breast cancer [31, 39]. In these connections, soy isoflavones have been reported to have a variety of biological activities including estrogenic [32], antioxidative [19], anti-osteoporotic [1] and anticarcinogenic [18] activities. Furthermore, recent clinical trials [2] and animal studies [4, 21, 33] also showed that dietary soy proteins or ISF reduce the risk factors for cardiovascular diseases, lowering triglyceride, total and low density lipoprotein (LDL) cholesterol levels and increasing the ratio of HDL/LDL cholesterol. However, the reported beneficial health effects were quite variable in different studies and the lack of understanding in the molecular mechanisms by which lipid metabolism is impacted, may contribute a major part to the discrepancies.

Soy proteins and ISF regulate lipid metabolism via multiple cellular pathways (fatty acid biosynthesis, cholesterol synthesis, catabolism and uptake) and through modulation of the key transcription factors including SREBP, PPAR, TR, RAR, and LXR [39]. The same multiple cellular pathways are disregulated in colon cancer [10, 23, 34-36].

Cholesterol is an essential component of cell membrane and the main pathway through which proliferating cells gain cholesterol is de novo synthesis of endogenous cholesterol regulated by the activity of 3-hydroxymethylglutaryl-coenzymeA (HMG-CoA) reductase. Alternatively, the cellular uptake of circulating LDL after binding to its receptor represents another mechanism of cholesterol acquisition. Several evidences have demonstrated that LDL receptor have a role in cell growth and tumorigenesis [8-10]. We, previously, showed that $63.3 \%$ of colon cancer patients did not present LDL receptors and 
that the absence of LDL receptor predicted shorter survival $[8,9]$. Additionally, the absence of LDL receptor in cancers was associated with enhanced endogenous cholesterol synthesis [10]. A loss of LDL receptor in tumors is expected to remove feedback inhibition of HMG-CoA reductase, stimulating endogenous mevalonate pathway [10]. Increased synthesis mevalonate and mevalonatederived isoprenoids supports increased cell proliferation through the activation of growth-regulatory proteins and oncoproteins and by promoting DNA synthesis [16]. In agreement with these observations the inhibition of mevalonate synthesis and the up-regulation of LDL receptor, therefore may be an effective strategy to impair the growth of colon malignant cells.

Factors that up-regulate LDL receptor gene include estrogen and phytoestrogen in HepG2 cells and in rat liver [7, 13, 15]. Moreover the inhibition of mevalonate synthesis may be exerted by plant isoprenoid and genistein on experimental breast cancer [16]. Genistein has been also shown to decrease cholesterol synthesis in cultured HepG2 [7] and inhibits HMG-CoA reductase activity in MCF-7 human breast cancer cells [17]. It has been suggested that the soy proteins enhance the expression of the LDL receptor in cultured human hepatoma cells [26], animals, and hypercholesterolemic Type 2 diabetic patients [24, 25]. A similar effect has been observed with a soy protein polypeptide in cultured HepG2 cells [27].

Previously, we have demonstrated an estrogenic regulation of cholesterol biosynthesis and cell growth in DLD-1 colon cancer cells. Estrogens induced an early increase of LDL receptor at both mRNA and protein level and later decrease of HMG-CoA reductase activity and protein expression [30].

Then, in the present study, we aimed to investigate whether genistein might affect gene expression of LDL receptor and HMG-CoA reductase in DLD-1 cells, a human colon cancer cell line expressing estrogen receptor $\beta$, but lacked estrogen receptor $\alpha$ [3]. If genistein regulation of LDL receptor and HMG-CoA reductase gene expression via estrogen receptor $\beta$ exists, the use of genistein might be a new approach for colon cancer management.

\section{Methods}

Cell culture condition

Human colon adenocarcinoma-derived DLD-1 cells were obtained from the Interlab Cell Line Collection (IST, Genoa, Italy). Cells were routinely cultured in RPMI 1640 without phenol red supplemented with $10 \%$ fetal bovine serum (FBS), $1 \%$ nonessential amino acids, $2 \mathrm{mM}$ glutamine, $100 \mathrm{U} / \mathrm{ml}$ penicillin, $100 \mu \mathrm{g} / \mathrm{ml}$ streptomycin, in monolayer culture, and incubated at $37^{\circ} \mathrm{C}$ in a humidified atmosphere containing $5 \% \mathrm{CO}_{2}$ in air. At confluence, the grown cells were harvested by means of trypsinization and serially subcultured with a 1:4 split ratio. All cell culture components were purchased from Sigma-Aldrich (Milan, Italy).

\section{Genistein treatment}

In the experiments investigating the effect of genistein under estrogen-depleted culture conditions, DLD-1 cells were seeded at a density of $2 \times 10^{5}$ cells $/ 5 \mathrm{ml}$ of phenol red-free RPMI 1640 containing 10\% FBS in $60 \mathrm{~mm}$ tissue culture dishes (Corning Costar Co., Milan, Italy). After $24 \mathrm{~h}$, to allow for attachment, the medium was removed, and RPMI 1640 containing 5\% dextran-coated charcoaltreated FBS was added to cell line.

The cells were incubated for further $24 \mathrm{~h}$, and then the medium was replaced by fresh culture medium containing 5\% charcoal-stripped FBS with genistein at increasing concentrations $(0.01,1,10$ and $50 \mu \mathrm{M})$ dissolved in dimethyl sulfoxide (DMSO). The cells were allowed to grow for established time and then trypsinized. The cell pellet obtained after low-speed centrifugation was used for subsequent analyses.

Before proceeding with the experiments, estrogen levels were evaluated in the estrogen stripped medium in which DLD-1 cells were seeded by using a specific radioimmunoassay; estrogen levels were found below the detection limit.

Each experiment included an untreated control and a control with the equivalent concentration of DMSO as had been used for adding phytoestrogen. The solvent reached a concentration not higher than $0.3 \%$ in all experiments.

Triplicate cultures were set up for each phytoestrogen concentration and for control, and each experiment was repeated four times.

Cell viability, determined using the trypan blue exclusion test, always exceeded $90 \%$.

\section{LDL receptor and HMG-CoA reductase gene} expression

DLD- 1 cells were cultured with $0.01,1,10$ and $50 \mu \mathrm{M}$ of genistein for $30 \mathrm{~min}, 1,2,5$ and $24 \mathrm{~h}$ in order to evaluate LDL receptor mRNA expression and for 24 and $48 \mathrm{~h}$ to analyze mRNA expression of HMG-CoA reductase. Very precocious times of exposure to genistein were tested because LDL-R gene is considered an early gene [5, 30], on the contrary longer times of exposure to genistein are required in order to detect an effect in HMG-CoAR gene expression [13, 30]. In parallel experiments, LDL-R mRNA levels were analysed in DLD-1 cells exposed for 
$5 \mathrm{~h}$ to genistein $(0.01 \mu \mathrm{M})$ alone and genistein $(0.01 \mu \mathrm{M})$ plus ICI $182,780(0.1 \mu \mathrm{M})$.

Analysis of gene expression was performed by reverse transcription followed by real-time PCR. Total cell RNA was isolated with TRI-Reagent (Mol. Res. Centre Inc. Cincinnati, O, USA), following the manufacturer's instruction. Briefly, DLD-1 cells, after exposure to different genistein concentrations, were washed twice in phosphate buffered saline (PBS), scraped in PBS, and vigorously shaken in $0.3 \mathrm{ml}$ of pure distilled water; then, $0.75 \mathrm{ml}$ of TRI-Reagent and $0.2 \mathrm{ml}$ of chloroform were added to cell lysate. The samples were vigorously shaken and centrifuged and the RNA present in the aqueous phase was precipitated with $0.5 \mathrm{ml}$ of isopropanol. The RNA pellet was washed once with $1 \mathrm{ml}$ of $75 \%$ ethanol, dried, resuspended in sterile water and quantified by UV absorbance. A sum of $2 \mu \mathrm{g}$ of total RNA were used for the reverse transcription reaction performed in $20 \mu \mathrm{l}$ of final volume at $41^{\circ} \mathrm{C}$ for $60 \mathrm{~min}$, using $30 \mathrm{pmol}$ of antisense primer (Table 1) for analyses of the HMG-CoA reductase, the LDL receptor and the $\beta$-actin gene. $\beta$-actin gene was utilized as an internal control and it was chosen as a reference gene because it is a housekeeping gene. Real-time PCRs were performed in $25 \mu \mathrm{l}$ of final volume containing $2 \mu \mathrm{l}$ of cDNA, master mix with SYBR Green (iQ SYBR Green Supermix Bio-Rad, Milan, Italy) and sense and antisense primers for each target gene. The expression of each gene analysed was detected in separated tubes.

Real-time PCR was carried out in iCycler Thermal Cycler System apparatus (Bio-Rad) using the following parameters: one cycle of $95^{\circ} \mathrm{C}$ for $1 \mathrm{~min}$ and $30 \mathrm{~s}$, followed by 45 cycles at $94^{\circ} \mathrm{C}$ for $10 \mathrm{~s}, 55^{\circ} \mathrm{C}$ for $10 \mathrm{~s}$ and $72^{\circ} \mathrm{C}$ for $30 \mathrm{~s}$ and a further melting curve step at $55-95^{\circ} \mathrm{C}$ with a heating rate of $0.5^{\circ} \mathrm{C}$ per cycle for 80 cycles. The PCR products were quantified by external calibration curves, one for each tested gene, obtained with serial dilutions of

Table 1 Sequences of amplification primers

\begin{tabular}{lc}
\hline Gene & Primer \\
\hline LDL receptor & \\
Sense & $5^{\prime}$-CAATGTCTCACCAAGCTCTG-3' \\
Antisense & $5^{\prime}$-TCTGTCTCGAGGGGTAGCTG-3' \\
HMG-CoA reductase & \\
Sense & $5^{\prime}$-TACCATGTCAGGGGTACGTC-3' \\
Antisense & $5^{\prime}$-CAAGCCTAGAGACATAATCATC \\
$\beta$-actin & \\
Sense & $5^{\prime}$-AAAGACCTGTACGCCAACACAGTG \\
Antisense & CTGTCTGG-3' \\
& $5^{\prime}$-CGTCATACTCCTGCTTGCT GATCC \\
\hline
\end{tabular}

known copy number of molecules $\left(10^{2}-10^{7}\right.$ molecules $)$. All expression data were normalized by dividing the amount of target by the amount of $\beta$-actin used as internal control for each sample. The specificity of the PCR product of each tested gene was confirmed by gel electrophoresis.

Assessment of cell proliferation

After DLD-1 cells had been cultured for $24 \mathrm{~h}$ with different concentrations of genistein $(0.01,1,10$ and $50 \mu \mathrm{M})$, proliferative response was estimated by $\left[{ }^{3} \mathrm{H}\right]$-thymidine incorporation and colorimetric MTT-test (Sigma-Aldrich) as previously reported $[28,29]$.

Statistical analysis

The significance of the differences between the control group and each experimental group was evaluated with one-way analysis of variance and the Dunnett' post test. Differences were considered significant at a $5 \%$ probability level.

\section{Results}

The exposure of DLD-1 to different concentrations of genistein, under estrogen-depleted culture conditions, determined an induction of LDL receptor gene expression. In fact, compared to control cells, a good time-dependency of the gene induction was at $1 \mu \mathrm{M}$ of genistein concentration, while a good dose-dependency was present after $2 \mathrm{~h}$ of hormone exposure (Table 2).

Genistein exerted a weak, but not significant, decrease in HMG-CoA reductase gene expression after $24 \mathrm{~h}$ of treatment. On the contrary, after $48 \mathrm{~h}$ of exposure to increasing concentrations of genistein, DLD-1 cells showed a significant decrease in HMG-CoA reductase mRNA expression starting to $1 \mu \mathrm{M}$ which was maintained for up $50 \mu \mathrm{M}$ (Table 3).

To evaluate whether the effect of genistein on LDL receptor mRNA expression in DLD-1 cells was mediated through the estrogen receptor, cells were also exposed to $0.01 \mu \mathrm{M}$ genistein for $5 \mathrm{~h}$ in the presence or absence of $0.1 \mu \mathrm{M}$ ICI 182,780 (a pure estrogen receptor antagonist). ICI 182,780 completely abolished the stimulation of LDL receptor gene induced after $5 \mathrm{~h}$ of exposure (Fig. 1).

Exposure of the DLD-1 cell line to increasing concentrations of genistein (from 0.01 to $50 \mu \mathrm{M}$ ) under estrogendepleted culture conditions showed an evident antiproliferative action, measured by ${ }^{3} \mathrm{H}$-thymidine incorporation and the colorimetric MTT method.

Figure 2 shows the effect of increasing concentrations of genistein on the incorporation of ${ }^{3} \mathrm{H}$-thymidine in DNA 
Table 2 Genistein effects on LDL receptor gene expression in DLD-1 cells

\begin{tabular}{lllcrr}
\hline Genistein & $30 \mathrm{~min}$ & $1 \mathrm{~h}$ & $2 \mathrm{~h}$ & $5 \mathrm{~h}$ & $24 \mathrm{~h}$ \\
\hline Control & $0.6 \pm 0.03$ & $0.62 \pm 0.01$ & $0.65 \pm 0.02$ & $0.63 \pm 0.05$ & $0.5 \pm 0.04$ \\
$0.01 \mu \mathrm{M}$ & $0.5 \pm 0.02$ & $0.6 \pm 0.05$ & $0.6 \pm 0.05$ & $1.2 \pm 0.01^{*}$ & $0.9 \pm 0.02^{*}$ \\
$1 \mu \mathrm{M}$ & $0.4 \pm 0.02$ & $0.5 \pm 0.04$ & $0.9 \pm 0.03$ & $1.1 \pm 0.02^{*}$ & $1.1 \pm 0.02^{*}$ \\
$10 \mu \mathrm{M}$ & $1.1 \pm 0.06^{*}$ & $0.9 \pm 0.02^{*}$ & $1.3 \pm 0.07^{*}$ & $1.0 \pm 0.02^{*}$ & $1.2 \pm 0.06^{*}$ \\
$50 \mu \mathrm{M}$ & $1.5 \pm 0.08^{*}$ & $1.2 \pm 0.06^{*}$ & $1.4 \pm 0.06^{*}$ & $1.2 \pm 0.05^{*}$ & $1.0 \pm 0.08^{*}$ \\
\hline
\end{tabular}

Data displayed as mean \pm SE of number molecules mRNA LDL receptor/number molecules mRNA $\beta$-actin. $P$ value was determined by oneway analysis with Dunnett's post-test. $* P<0.05$ versus control. Results derived from triplicate cultures set up for each phytoestrogen concentration and for control, and each experiment was repeated four times

Table 3 Genistein effects on HMG-CoA reductase gene expression in DLD-1 cells

\begin{tabular}{lrr}
\hline Genistein & \multicolumn{1}{l}{ 24 h } & \multicolumn{1}{c}{$48 \mathrm{~h}$} \\
\hline Control & $1.04 \pm 0.03$ & $1.02 \pm 0.01$ \\
$0.01 \mu \mathrm{M}$ & $1.03 \pm 0.01$ & $0.8 \pm 0.01$ \\
$1 \mu \mathrm{M}$ & $1.02 \pm 0.01$ & $0.6 \pm 0.02^{*}$ \\
$10 \mu \mathrm{M}$ & $0.92 \pm 0.04$ & $0.5 \pm 0.01^{*}$ \\
$50 \mu \mathrm{M}$ & $0.8 \pm 0.02$ & $0.6 \pm 0.05^{*}$
\end{tabular}

Data displayed as mean \pm SE of number molecules mRNA HMGCoA reductase/number molecules mRNA $\beta$-actin. $P$ value was determined by one-way analysis with Dunnett's post-test. $* P<0.05$ versus control. Results derived from triplicate cultures set up for each phytoestrogen concentration and for control, and each experiment was repeated four times

of DLD-1 cells after $24 \mathrm{~h}$. Concentrations equal to or higher than $10 \mu \mathrm{M}$ of the isoflavone caused a significant reduction of cell proliferation.

As with ${ }^{3} \mathrm{H}$-thymidine incorporation, the formazangenerated MTT decreased in dose-dependent manner, from 0.01 to $50 \mu \mathrm{M}$ of genistein concentrations after $24 \mathrm{~h}$ of exposure (data not shown).

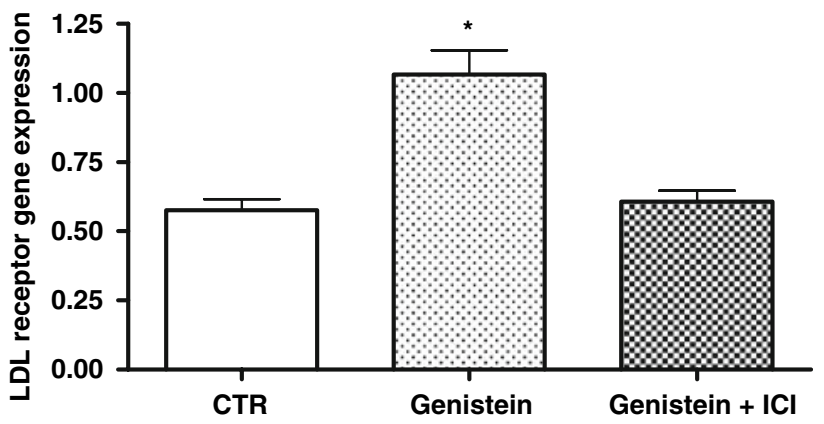

Fig. 1 LDL-R mRNA levels in DLD-1 cells exposed for $5 \mathrm{~h}$ to genistein $(0.01 \mu \mathrm{M})$ alone and genistein $(0.01 \mu \mathrm{M})$ plus ICI 182,780 $(0.1 \mu \mathrm{M})$. Data displayed as mean $\pm \mathrm{SE}$ of number molecules mRNA LDL receptor/number molecules mRNA $\beta$-actin. $P$ value was determined by one-way analysis with Dunnett' post-test. ${ }^{*} P<0.05$ versus control (CTR)

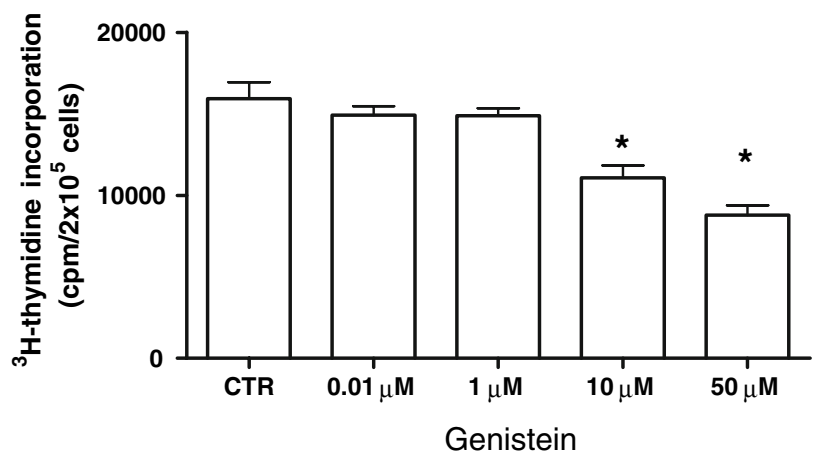

Fig. 2 Effects of increasing genistein concentrations on ${ }^{3} \mathrm{H}$-thymidine incorporation in DNA of DLD-1 cells after $24 \mathrm{~h}$ of hormonal treatment. Data displayed as mean \pm SE. $* P<0.05$ Dunnett's multiple comparisons test versus control (CTR)

\section{Discussion}

Factors that up-regulate LDL receptor expression in normal and neoplastic cells include multiple growth factors, many hormones (such as insulin, glucagons, growth hormone) and steroid hormones, such as estrogens. Some authors have demonstrated, both in vivo and in vitro, a stimulation of LDL receptor mRNA and protein expression in hepatoma cell line HepG2 and in rat liver by a natural estrogen, $17 \beta$-estradiol, suggesting an estrogen regulation of hepatic LDL receptor expression [13, 15]. Recently, it has been showed that diets containing soy protein enhance the clearance of apoB-containing lipoproteins via LDL receptors expressed on the hepatocyte plasma membrane [7].

Dietary factors may regulate HMG-CoA reductase activity with implications for breast cancer development [16]. Kojima et al. have demonstrated that genistein itself and/or its metabolites may suppress hepatic lipid synthesis [20].

In this report, we show that LDL receptor and HMGCoA reductase gene expression are affected by genistein in DLD-1 cell line. The phytoestrogen genistein is present in relatively high amounts in soybeans and it is able to induce LDL receptor gene expression and down-regulate HMG- 
CoA reductase gene in DLD- 1 cells via estrogen receptor $\beta$. The effect of genistein treatment on LDL receptor gene expression was dose-dependent after $2 \mathrm{~h}$. A good timedependency was present at $1 \mu \mathrm{M}$ of genistein.

In addition, genistein, exerted an evident antiproliferative action on DLD-1 cells in a dose-dependent manner.

These findings provide direct evidence of the relationship between phytoestrogens and cholesterol pathway, representing a promising basis for the comprehension of the mechanism of estrogen and phytoestrogens action in gastrointestinal tract. We have already showed that estrogens modulate the colon cancer proliferation by the up regulation of LDL receptor and the down regulation of HMG-CoA reductase activity [30], suggesting that the cholesterol metabolism could be considered an additional target for the estrogenic antiproliferative properties in colon cancer.

The estrogen-gene regulated transcription utilizes different pathways depending on the cellular contex. It is known that at hepatic level the induction of LDL receptor gene by estrogen is mediated by non transcriptional factors, but if a similar mechanism exists in colon cells is not currently known. Moreover, genistein is also a tirosyne kinase inhibitor and therefore can affect the cell signal transduction pathway through this way. Further studies are required to identify this molecular mechanism.

HMG-CoA reductase is the key enzyme of mevalonate biosynthesis [37]. A reduction of the HMG-CoA reductase expression by genistein may decrease the mevalonate pool, thus limiting protein isoprenylation, which involves the post-translational covalent attachment of a lipophilic farnesyl or geranylgeranyl isoprenoid group to several proteins [11]. Many prenylated proteins, like Ras, lamin B, and Rho regulate cell growth and/or transformation. The up-regulation of LDL receptor by genistein make to an increased cholesterol intracellular content, modulating HMG-CoA reductase gene expression and consequently controlling cell proliferation and transformation.

Our findings support a variety of studies that have linked the soy-derived isoflavones, such as genistein, with antitumorigenic activity $[6,12]$. Genistein has been demonstrated to reduce proliferation and induce $\mathrm{G} 2 / \mathrm{M}$ phase arrest and apoptotic death in colon cancer HT-29 cells [40]. Genistein increased expression of Bax and p21WAF1 and slightly decreased Bcl-2 level and resulted to inhibit the viability of human colon cancer HT-29 cells via induction of apoptosis. In a previous study, we showed that genistein can affect growth of DLD-1 cells by both decreasing polyamine biosynthesis and inducing apoptosis [22]. It is known that high polyamine levels are associated with fast proliferating cells [38] and that polyamine levels in colon cancer are significantly increased compared to normal and preneoplastic tissue [14]. Therefore, the reduction of polyamine levels represents an antiproliferative mechanism, offered by genistein, against colon cancer growth. Genistein produces suggestive effects for estrogenicity given that it can induce estrogen-responsive gene products, as LDL receptor. This estrogen agonistic activity of genistein may account for the beneficial effects of this compound against colon cancer development. A central role of genistein in prevention of colon tumor and in reduction of colon tumor growth might be considered.

\section{References}

1. Anderson JJB, Garner SC (1997) The effects of phytoestrogens on bone. Nutr Rev 17:1617-1632

2. Anderson JW, Jhonstone BM, Cook N (1995) Meta-analysis of the effects of soy protein intake on serum lipids. N Engl J Med 333:276-282

3. Arai N, Strom A, Rafter JJ, Gustafsson (2000) Estrogen receptor $\beta$ mRNA in colon cancer cells: growth effects of estrogen and genistein. Biochem Biophys Res Comm 270:425-431

4. Ascenscio C, Torres N, Isoard-Acosta F, Gomez-Perez FJ, Hernandez-Pando R, Tovar AR (2004) Soy protein affects serum insulin and hepatic SREBP-1 mRNA and reduces fatty liver in rats. J Nutr 134:522-529

5. Bocchetta M, Bruscalupi G, Castellano F, Trentalance A, Komaromy M, Fong LG, Cooper AD (1993) Early induction of LDL receptor gene during rat liver regeneration. J Cell Physiol 156:601-609

6. Booth C, Hargreaves Df, Hadfield JA, McGown AT, Potten CS (1999) Isoflavones inhibit intestinal epithelial cell proliferation and induce apoptosis in vitro. Br J Cancer 80:1550-1557

7. Borradaile NM, de Dreu LE, Wilcox LJ, Edwards JY, Huff MW (2002) Soya phytoestrogens, genistein and daidzein, decrease apolipoprotein B secretion from HepG2 cells through multiple mechanisms. Biochem J 366:531-539

8. Caruso MG, Notarnicola M, Cavallini A, Guerra V, Misciagna G, Di Leo A (1993) Demonstration of low density lipoprotein receptor in human colonic carcinoma and in surrounding mucosa by immunoenzymatic assay. Ital J Gastroenterol 25:361-367

9. Caruso MG, Osella AR, Notarnicola M, Berloco P, Leo S, Bonfiglio C, Di Leo A (1998) Prognostic value of low density lipoprotein receptor expression in colorectal carcinoma. Oncol Rep 5:927-930

10. Caruso MG, Notarnicola M, Santillo M, Cavallini A, Di Leo A (1999) Enhanced 3-HMGCoA reductase activity in human colorectal cancer not expressing low density lipoprotein receptor. Anticancer Res 19:451-454

11. Clarke S (1992) Protein isoprenylation and methylation at carboxyl-terminal cystein residue. Annu Rev Biochem 61:355-86

12. Crowell PL (1999) Prevention and therapy of cancer by dietary monoterpenes. J Nutr 129:775S-778

13. Di Croce L, Bruscalupi G, Trentalance (1996) Independent behaviour of rat liver LDL receptor and HMGCoA reductase under estrogen treatment. Biochem Biophys Res Comm 224:345-350

14. Di Leo A, Messa C, Russo F, Misciagna G, Guerra V, Taveri R, Leo S (1994) Prognostic value of cytosolic estrogen receptors in human colorectal carcinoma and surrounding mucosa. Preliminary results. Dig Dis Sci 9:2038-2042

15. Di Stefano E, Marino M, Gillette JA, Hanstein B, Pallottini V, Bruning J, Krone W, Trentalance A (2002) Role of tyrosine kinase signaling in estrogen-induced LDL receptor gene expression in HepG2 cells. Biochim Biophys Acta 1580:145-149 
16. Duncan RE, El-Sohemy A, Archer MC (2005) Dietary factors and the regulation of 3-hydroxy-3-methylglutaryl coenzyme A reductase: implication for breast cancer and development. Mol Nutr Food Res 49:93-100

17. Dyck JRB, Kudo N, Barr AJ, Davies SP, Hardie DG, Lopaschuk GD (1999) Phosphorylation control of cardiac acetyl-CoA carboxylase by cAMP-dependent protein kinase and $5^{\prime}$-AMP activated protein kinase. Eur J Biochem 262:184-190

18. Herman C, Adlercreutz T, Goldin BR, Gorbach SL, Hockerstedt KAV, Watanabe S, Hamalainen EK, Markkanen MH, Makela TH, Wahala KT, Hase TA, Fotsis T (1995) Soybean phytoestrogen intake and cancer risk. J Nutr 125:757S-770S

19. Kapiotis S, Herman M, Held I, Seelos C, Ehringer H, Gmeiner BM (1997) Genistein, the dietary-derived angiogenesis inhibitor, prevents LDL oxidation and protects endothelial cells from damage by atherogenic LDL. Arterioscler Thromb Vasc Biol 17:2868-2874

20. Kojima T, Uesuqi T, Toda T, Miura Y, Yagasaki K (2002) Hypolipidemic action of the soybean isoflavones genistein and genistein in glomerulonephritic rats. Lipids 37:261-265

21. Lin Y, Meijer GW, Vermer MA, Trautwein EA (2004) Soy protein enhances the cholesterol-lowering effect of plant sterol esters in cholesterol-fed hamster. J Nutr 134:143-148

22. Linsalata M, Russo F, Notarnicola M, Guerra V, Cavallini A, Clemente C, Messa C (2005) Effects of genistein on the polyamine metabolism and cell growth in DLD-1 human colon cancer cells. Nutr Cancer 52:83-92

23. Linsalata M, Giannini R, Notarnicola M, Cavallini A (2006) Peroxisome proliferator-activated receptor gamma and spermidine/spermine N1-acetyltransferase gene expressions are significantly correlated in human colorectal cancer. BMC Cancer 6:191-198

24. Lovati MR, Manzoni C, Canadesi A, Sirtori M, Vaccarino V, Marchi M, Gaddi G, Sirtori CR (1987) Soybean protein diet increases low density lipoprotein receptor activity in mononuclear cells from hypercholesterolemic patients. J Clin Invest 80:1498-1502

25. Lovati MR, Manzoni C, Agostinelli P, Ciappellano S, Mannucci L, Sirtori CR (1991) Studies on the mechanism of the cholesterol lowering activity of soy proteins. Nutr Metab Cardiovasc Dis $1: 18-24$

26. Lovati MR, Manzoni C, Gianazza E, Sirtori CR (1998) Soybean protein products as regulators of liver low-density lipoprotein receptors. I. Identification of active b-conglycinin subunits. J Agric Food Chem 46:2474-2480

27. Manzoni C, Lovati MR, Gianazza E, Sirtori CR (1998) Soybean protein products as regulators of liver low-density lipoprotein receptors. II a-a' rich commercial soy concentrate an $\mathrm{a}^{\prime}$ deficient mutant differently affect low-density lipoproetin receptor activation. J Agric Food Chem 46:2481-2484

28. Messa C, Pricci M, Linsalata M, Russo F, Di Leo A (1999) Inhibitory effect of $17 \beta$-estradiol on growth and the polyamine metabolism of a human gastric carcinoma cell line (HGC-27). Scand J Gastroenterol 34:79-84

29. Messa C, Russo F, Pricci M, Di Leo A (2000) Epidermal growth factor and $17 \beta$-estradiol effects on proliferation of a human gastric cancer cell lines (AGS). Scand J Gastroenterol 35:753-58

30. Messa C, Notarnicola M, Russo F, Cavallini A, Pallottini V, Trentalance A, Bifulco M, Laezza C, Caruso MG (2005) Estrogenic regulation of cholesterol biosynthesis and cell growth in DLD-1 human colon cancer cells. Scand J Gastroenterol 40:1454-1461

31. Messina M, Persky V, Setchell KDR, Barnes S (1994) Soy intake and cancer risk: a review of the in vitro and in vivo data. Nutr Cancer 21:113-131

32. Messina M (2000) Soyfoods and soybean phyto-oestrogens (isoflavones) as a possible alternative to hormone replacement therapy (HRT). Eur J Cancer 36:71S-72S

33. Moriyama T, Kishimoto K, Nagai K, Urade R, Ogawa T, Utsumi S, Maruyama N, Maebuchi M (2004) Soybean beta-conglycin diet suppress serum triglyceride levels in normal and genetically obese mice by induction of beta-oxidation, down-regulation of fatty acid synthase and inhibition of triglyceride absorption. Biosci Biotechnol Biochem 68:352-359

34. Notarnicola M, Messa C, Cavallini A, Bifulco M, Tecce MF, Eletto D, Di Leo A, Montemurro S, Laezza C, Caruso MG (2004) Higher farnesyl diphosphate synthase activity in human colorectal cancer: inhibition of cellular apoptosis. Oncology 67:351-358

35. Notarnicola M, Altomare DF, Calvani M, Orlando A, Bifulco M, D'Attoma B, Caruso MG (2007) Fatty acid synthase hyperactivation in human colorectal cancer: relationship with tumor side and sex. Oncology 71:327-332

36. Rao KN (1995) The significance of cholesterol biosynthetic pathway in cell growth and carcinogenesis. Anticancer Res 15:309-314

37. Siperstein MD (1984) Role of cholesterogenesis and isoprenoid synthesis in DNA replication and cell growth. J Lipid Res 25:1462-1468

38. Tabor CW, Tabor H (1984) Polyamines. Annu Rev Biochem 53:749-790

39. Xiao CW, Mei J, Wood CM (2008) Effect of soy proteins and isoflavones on lipid metabolism and involved gene expression. Front Biosci 13:2660-2673

40. Yu Z, Li W, Liu F (2004) Inhibition of proliferation and induction of apoptosis by genistein in colon cancer HT-29 cells. Cancer Lett 215:159-166 